\title{
Penggunaan Media Sosial dalam Membangun Moderasi Beragama di Masa Pandemi Covid-19 di Kota Tangerang
}

\author{
Washilatun Novia ${ }^{1^{*}}$ dan Wasehudin Wasehudin ${ }^{2}$ \\ 1 UIN Sultan Maulana Hasanuddin Banten, Indonesia; e-mail: washilatunnovia16@gmail.com \\ 2 UIN Sultan Maulana Hasanuddin Banten, Indonesia; e-mail: wasehudin@uinbanten.ac.id \\ * Correspondence
}

Received: 2020-10-21; Accepted: 2020-10-26; Published: 2020-12-31

\begin{abstract}
This article reflects diversity during the Covid-19 pandemic in Tangerang City. The Covid19 Pandemic period requires all activities to be carried out online. This makes the use of social media unavoidable. This study used a descriptive qualitative method with observation and interviews as a technique used for data collection. The results of the study reveal that the active and massive use of social media to exchange information causes a wise attitude in dealing with the information received is needed. An attitude of wisdom, moderation, tolerance, and fairness is a reflection of moderation. The widespread use of social media and used as the main tool for activities, has made social media an educational tool for religious moderation. Parties such as religious leaders, educators, public figures, or even the public can spread the notion of religious moderation to the public through their respective activities, some of which include studies and lectures, millennial educational content, and educational comics on social media. This study recommends that parties involved in the world of education and propagation can instill an understanding of religious moderation with various media, including social media.
\end{abstract}

Keywords: covid-19; diversity; moderation; social media

\begin{abstract}
Abstrak: Artikel ini mendiskusikan tentang keberagamaan semasa pandemi Covid-19 di Kota Tangerang. Masa Pandemi Covid-19 mengharuskan seluruh aktivitas dilakukan secara daring. Hal tersebut mengakibatkan penggunaan media sosial tidak dapat dihindari. Penelitian ini menggunakan metode kualitatif deskriptif dengan observasi dan wawancara sebagai teknik yang digunakan untuk pengumpulan datanya. Hasil penelitian mengungkapkan bahwa penggunaan media sosial yang aktif dan masif untuk bertukar informasi, menyebabkan sikap yang bijak dalam menyikapi informasi yang diterima sangat dibutuhkan. Sikap bijak, tidak ekstrim, sikap toleransi, dan adil adalah cermin dari sikap moderasi. Maraknya penggunaan media sosial dan dijadikan sebagai alat utama untuk beraktivitas, membuat media sosial dapat dijadikan sebagai alat edukasi moderasi beragama. Pihak seperti pemuka agama, tenaga pendidik, publik figur, atau bahkan masyarakat dapat menyebarkan paham moderasi beragama kepada masyarakat melalui aktivitasnya masing-masing, beberapa contoh diantaranya seperti kajian dan ceramah, konten edukasi milenial, dan komik edukasi di media sosial. Kajian ini merekomendasikan agar pihak-pihak yang berkecimpung di dunia pendidikan dan dakwah dapat menanamkan paham moderasi beragama dengan berbagai media, termasuk media sosial.
\end{abstract}

Kata Kunci: covid-19; keberagamaan; media sosial; moderasi

\section{Pendahuluan}

Pluralisme adalah suatu bentuk paham atas keberagaman dan kemajemukan (Saraswati, 2013; Wibisono, 2016). Pluralisme sangat tergambarkan dalam kehidupan bermasyarakat di Indonesia karena Indonesia merupakan negara dengan beragam agama dan suku (T. Rahman, 2013). 
Keberagaman atas agama, suku, ras, dan adat istiadat di Indonesia ditunjukkan oleh data yang dihasilkan Badan Pusat Statistik (BPS) berkolaborasi dengan Institute of Southeast Asian Studies (ISEAS) pada tahun 2013 mengenai analisis atas pengelompokkan penyebaran suku di Indonesia. Berdasarkan data tersebut, suku Jawa memiliki proporsi sekitar $40 \%$ dari total penduduk Indonesia. Sementara, suku Sunda memiliki proporsi sebesar $15,5 \%$ dari jumlah penduduk Indonesia, sementara suku-suku lainnya memiliki proporsi di bawah $5 \%$ dari total penduduk di Indonesia.

Kemudian data suku diukur berdasarkan Ethnic Fractionalize Index (EFI) dan Ethnic Polarized Index (EPOI) menghasilkan nilai 0,8 dan 0,5 (Ananta dkk., 2015). Data tersebut menunjukkan sekaligus membuktikan jika pluralisme merupakan gaya hidup masyarakat Indonesia, sehingga dijadikan pedoman hidup bangsa yaitu Bhinneka Tunggal Ika. Beragamnya suku menyebabkan ajaran agama yang ada di Indonesia juga bervariasi. Beragamnya agama di Indonesia mengakibatkan prinsip beragama yang tumbuh di Indonesia pun juga beragam (M. T. Rahman \& Saebani, 2018).

Hal tersebut mengakibatkan memiliki sikap adil dan bijak dalam menyikapi segala sesuatu menjadi sebuah keharusan bagi seluruh masyarakat Indonesia. Sikap adil dan bijak dalam menyikapi perbedaan dan segala permasalahan yang timbul akibat dari perbedaan tersebut dapat disebut sebagai moderasi. Pemahaman moderasi diartikan sebagai paham menjaga keadilan dan keseimbangan. Moderasi di Indonesia ditunjukkan dengan sikap saling toleransi untuk menghormati perbedaan (Arenggoasih dan Wijayanti, 2020).

Moderasi beragama berarti tidak ekstrim dalam menerapkan ajaran agama. Ekstremisme, radikalisme, dan ujaran kebencian seringkali dihadapi oleh masyarakat Indonesia sehingga berdampak pada retaknya hubungan antar umat beragama, sehingga pengamalan paham moderasi beragama sangat penting adanya. Industri 4.0 menyebabkan segala aktivitas melibatkan teknologi, serta proses penyampaian dan perolehan informasi pun menjadi sesuatu yang sangat mudah untuk dilakukan. Media sosial merupakan salah satu bagian dari teknologi dan informasi yang pesat penggunaan dan perkembangannya.

Hasil survey We Are Social pada awal tahun 2019, menunjukkan bahwa pengguna internet termasuk di dalamnya penggunaan media sosial meningkat tajam hingga mencapai $57 \%$ dari total penduduk dunia. Data tersebut merupakan hasil pada bulan Januari 2019. Asia tenggara, termasuk Indonesia, menunjukkan data pengguna media sosial sebesar 61\% (We Are Social dan Hootsuite, 2019). Hal tersebut menunjukkan bahwa aktivitas pertukaran informasi melalui media sosial sangat aktif dan masif.

Informasi yang masif menjadikan masyarakat harus dapat memilah informasi yang diterimanya secara adil dan bijak. Penggunaan internet dan media sosial yang pesat di awal tahun 2019 semakin meningkat tajam grafiknya sejak pandemi COVID-19 melanda dunia. Pandemi COVID-19 menyebabkan seluruh masyarakat beraktivitas dengan melibatkan internet, sehingga penggunaan media sosial pun tidak dapat dihindarkan. Keterbatasan ruang gerak akibat pandemi, menyebabkan seluruh masyarakat di dunia, termasuk Indonesia, sangat bergantung pada informasi yang mereka dapatkan melalui media sosial yang mereka miliki (Muhyidin, Rosyad, Rahman, \& Huriani, 2020).

Kebijakan yang diambil seluruh negara di dunia dampak dari pandemi COVID-19 menyentuh seluruh aspek kehidupan bernegara tersebut, tidak terkecuali sektor keagamaan. Keputusan yang dibuat oleh negara terhadap seluruh sektor kehidupan bernegara seringkali menuai protes dari masyarakat negara tersebut, termasuk keputusan di sektor keagamaan yang seringkali dikaitkan dengan prinsip keagamaan. Pada kondisi tersebut, maka sikap moderasi beragama perlu untuk diimplementasikan. Moderasi beragama dalam penggunaan media sosial sangat dibutuhkan.

Melalui sikap moderasi beragama, terutama saat pandemi COVID-19 yang seluruh aktivitasnya dilakukan melalui media sosial, akan mencegah hal tidak diinginkan seperti informasi yang memecah belah umat beragama terjadi. Oleh karena itu, dalam penelitian ini bertujuan untuk menunjukkan peran media sosial sebagai sarana moderasi beragama kepada masyarakat selama pandemi COVID19. Selain itu, pada penelitian ini juga bertujuan untuk menunjukkan bagaimana cara menggunakan media sosial selama pandemi COVID-19 sebagai sarana moderasi beragama di tengah masyarakat di Indonesia, khususnya di Kota Tangerang. 


\section{Metode Penelitian}

Metode penelitian yang digunakan dalam kajian peran media sosial dalam membangun moderasi beragama pada masa pandemi COVID-19 di Kota Tangerang ini menggunakan metode analisis deskriptif dengan pendekatan kualitatif, serta metode observasi langsung melalui hasil wawancara. Menurut Moleong (Lexy J, 2019), analisis kualitatif merupakan analisis dengan prosedur penelitian yang menghasilkan data deskriptif berupa kata-kata tertulis baik lisan maupun perilaku dari narasumber yang diamati. Analisis deskriptif akan menyajikan gambaran lengkap mengenai keadaan sosial, dengan maksud sebagai hasil eksplorasi dan klarifikasi mengenai suatu fenomena. Hasil metode penelitian deskriptif dengan pendekatan kualitatif dan observasi langsung melalui hasil wawancara, bertujuan untuk menemukan solusi atas permasalahan yang sedang dihadapi.

Langkah-langkah metode penelitian yaitu mengumpulkan data, klasifikasi dan analisis, pengolahan data, serta membuat kesimpulan dan laporan. Tujuan langkah metode penelitian tersebut adalah membentuk gambaran mengenai keadaan secara objektif. Langkah metode penelitian dapat dilihat pada Gambar 1.

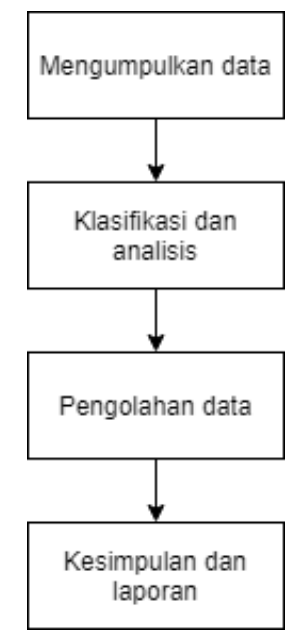

Gambar 1 Langkah Metode Penelitian

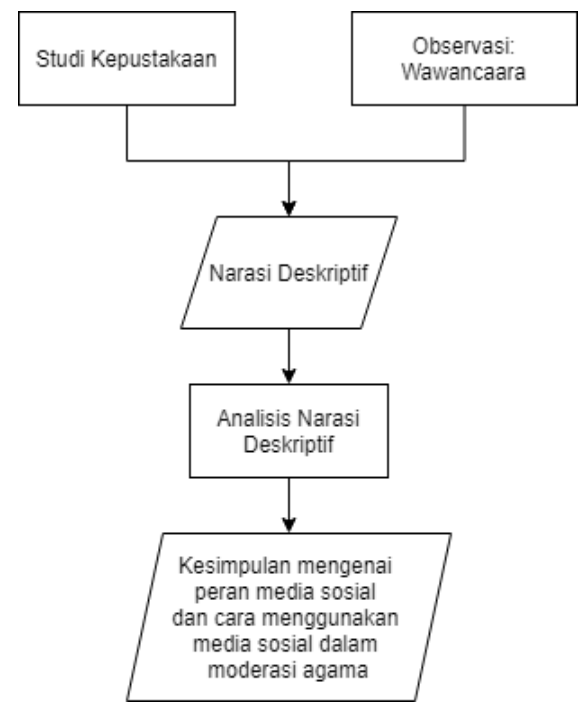

Gambar 2 Tahapan Metodologi Penelitian

Teknik pengumpulan data yang dilakukan pada penelitian ini dengan cara studi kepustakaan (library research) dari berbagai sumber tertulis, serta teknik wawancara terstruktur yang 
memperhatikan unsur $5 \mathrm{~W}+1 \mathrm{H}$. Teknik wawancara yang dilakukan fokus terhadap topik kajian peran media sosial dalam moderasi beragama pada masa pandemi COVID-19, khususnya di Kota Tangerang. Selanjutnya, data hasil wawancara akan dipaparkan dalam bentuk narasi deskriptif. Narasi deskriptif kemudian dianalisis dengan menggunakan teori dan referensi literatur yang relevan dengan topik kajian (Deddy, 2018). Hasil dari analisis terhadap narasi deskriptif adalah kesimpulan penelitian terkait topik penelitian yaitu informasi mengenai peran media sosial dalam moderasi agama, serta cara menggunakan media sosial sebagai sarana moderasi keagamaan di masa pandemi COVID-19.

Urutan langkah metode penelitian dapat dilihat pada Gambar 2.

Pada penelitian ini, data yang didapatkan merupakan hasil observasi wawancara yang dilakukan di wilayah Kota Tangerang. Narasumber wawancara pada penelitian ini berjumlah 15 orang. Narasumber tersebut antara lain lima pemuka agama di Kota Tangerang, lima guru Agama Islam Sekolah Menengah Atas di Kota Tangerang, dan lima pegawai Kelurahan di salah satu kelurahan di Kota Tangerang.

\section{Hasil Penelitian}

Pandemi COVID-19 yang sedang melanda seluruh dunia, termasuk Indonesia, telah mengguncang segala aspek kehidupan manusia. COVID-19 dapat menularkan ke siapapun dalam waktu yang singkat. Setiap orang memiliki potensi yang sama untuk terjangkit apabila kondisi kesehatan tubuh tidak baik dan prima. Seseorang akan lebih mudah untuk terjangkit COVID-19 apabila tidak menerapkan pola hidup bersih dan sehat, seperti yang telah digaungkan oleh semua pihak. Selain menerapkan pola hidup bersih dan sehat, semua pihak juga harus menerapkan gaya hidup baru yaitu menjaga jarak antar individu (physical distancing) guna mencegah penularan COVID19.

Gaya hidup baru yang diterapkan pada masa pandemi COVID-19 selain menjaga jarak yaitu anjuran untuk melakukan segala aktivitas mulai dari belajar mengajar, bekerja, bahkan beribadah dari rumah. Fakta tersebut sejalan dengan hasil temuan penulis melalui studi literatur pada penelitian yang dilakukan oleh Saenong (Saenong dkk., 2020). Seruan untuk beraktivitas dari rumah mengakibatkan seluruh masyarakat menggunakan teknologi untuk melakukan pekerjaannya. Penggunaan teknologi terutama media sosial menjadi aktivitas utama di tengah masyarakat agar tetap dapat terhubung dengan orang lain dan mengetahui informasi mengenai dunia luar. Fakta tersebut juga tertuang dalam penelitian Purwanto (Purwanto dkk., 2020).

Dampak COVID-19 dalam bidang keagamaan mengakibatkan tejadinya pembatasan aktivitas ibadah. Seluruh tempat ibadah untuk sementara waktu ditutup guna mencegah peluang terjadinya penularan COVID-19 melalui aktivitas berkumpul yang terjadi saat beribadah. Hal tersebut merupakan bentuk implementasi dari kebijakan dan seruan yang dibuat pemerintah. Hal tersebut menghasilkan respon yang beragam dari masyarakat.

Seluruh tempat ibadah dari berbagai agama mengimplementasikan peraturan tersebut, termasuk agama Islam. Segala bentuk kegiatan ibadah seperti shalat berjamaah, shalat jum'at, kajian, dan ceramah untuk sementara waktu ditiadakan. Sebagian masyarakat memahami bahwa penutupan tempat ibadah karena COVID-19 merupakan sesuatu yang wajar dilakukan. Akan tetapi, sebagian lainnya merasa berat terhadap kebijakan penutupan dan peniadaan sementara tempat ibadah tersebut. Oleh karena itu, moderasi beragama menjadi suatu hal yang perlu dipahami dan diimplementasikan secara mutlak dan maksimal dalam situasi pandemi seperti ini.

Allah SWT berfirman dalam QS. Al-Anfal/8: 25: "Dan peliharalah dirimu dari pada siksaan yang tidak khusus menimpa orang-orang yang lalim saja di antara kalian. Dan ketahuilah bahwa Allah amat keras".

Masyarakat harus mampu bersikap moderat dalam menjalani perubahan gaya hidup akibat pandemi dan bersikap terbuka pada berbagai aspek baru yang mengharuskan masyarakat untuk beradaptasi. Media sosial menjadi perhatian dalam penelitian ini karena merupakan sarana utama masyarakat dalam beraktivitas sehari-hari untuk mendapatkan informasi dan memberikan informasi. Terlebih di masa pandemi, pengaksesan terhadap media sosial semakin meningkat tajam dan menjadi 
sebuah kebutuhan dasar. Hal tersebut merupakan hasil analisis studi literatur yang peneliti lakukan pada penelitian yang dilakukan Sampurno (Sampurno dkk., 2020).

Berdasarkan hasil wawancara terstruktur yang dilakukan peneliti terhadap beberapa narasumber yang telah dilakukan serta didukung dengan hasil literatur, mengenai pandangan terhadap peran media sosial pada moderasi keagamaan selama pandemi COVID-19, didapatkan data berikut. Kegiatan wawancara peneliti lakukan terhadap 15 narasumber. Masing-masing narasumber diberikan pertanyaan seputar COVID-19, keagamaan, dan media sosial. Ketiga topik pertanyaan tersebut merupakan topik yang saling berkaitan dan merupakan topik utama selama masa pandemi ini.

Hasil wawancara dipaparkan dalam bentuk paragraf narasi deskriptif. Berikut pertanyaan yang diajukan peneliti terhadap narasumber: "Upaya usaha yang dilakukan para pemimpin agama dalam menyikapi dan menyiarkan keberagaman agama diseluruh dunia pada masa pandemi COVID-19 sekarang ini?" Terhadap pertanyaan tersebut, narasumber 1 mengungkapkan bahwa "Semakin lama, agama semakin berperan dan dominan. Diketahui bahwa selama pandemi, keberagaman agama diseluruh dunia telah menunjukkan peran pentingnya dalam mencegah penyebaran COVID-19. Dalil untuk mendukung kebijakan pemerintah mengenai karantina diilhami dari kutipan hadist Nabi Muhammad SAW, yaitu "Jika Anda mendengar wabah terjadi di suatu wilayah, janganlah kalian memasuki wilayah tersebut; dan jika wabah itu terjadi di suatu tempat saat Anda ada di dalamnya, janganlah meninggalkan tempat itu "

Berdasarkan hasil literatur yang peneliti lakukan, didapatkan informasi bahwa para pemuka agama di Taiwan melakukan kerjasama dengan pusat pemerintahan untuk merespons COVID-19 secara cepat dengan tujuan untuk melindungi masyarakat. Sehingga, negara Taiwan inilah dapat dianggap berhasil menangani COVID-19. Sementara itu sebagai perbandingan, Vatikan telah beradaptasi dan mengubah literasi daring dalam penyediakan pedoman doa-doa baru untuk mengantisipasi penyebaran pandemi dengan menyajikan pedoman beribadah secara lebih ringkas dan lebih mengutamakan keselamatan kesehatan umat banyak dengan memperhatikan protokol pada masing-masing kebijakan. Selain itu, organisasi keagamaan di Bangladesh juga dengan cepat menanggapi respons terhadap krisis kesehatan dengan menawarkan dukungan dalam arti kebutuhan secara spiritual dan material kepada masyarakat yang terkena dampak bencana.

Selain itu, pertanyaan yang diajukan peneliti terhadap narasumber, "Apa yang membedakan kegiatan beragama selama masa pandemi atau sebelum terjadinya pandemi Covid-19?" Terhadap pertanyaan tersebut, narasumber 6 mengungkapkan bahwa "Paham moderasi beragama harus terus diliterasikan guna mencegah perilaku esktrim yang dapat mengancam kehidupan berbangsa, beragama, dan bernegara. Mengenai hal tersebut, hal yang dimoderasi adalah pemahaman dan pengaplikasian tentang agama yang dianut. Tiga langkah intensif yang dilakukan akademisi, peneliti, cendekiawan, dan para ulama di lingkungan masa pandemi COVID-19 yaitu pertama, menentukan parameter moderasi beragama. Kedua, memetakan kebijakan keagamaan dan pemerintahan. Ketiga, para peneliti membuat penelitian ilmiah yang berkontribusi pada kemajuan ilmu penanganan dan pencegahan pandemi. Selain itu, pelaksanaan program pemerintah yaitu menggalakkan program kajian secara online dengan memanfaatkan platform-platform media sosial untuk membagikan ilmu mengenai pengetahuan keagamaan dengan tujuan meminimalisir penyebaran COVID-19.".

Kementerian Agama telah mengedukasi mengenai moderasi beragama sejak 5 tahun terakhir. Paham edukasi yang dikembangkan mengajarkan para penganut agama dalam menjalankan ajaran agama untuk tidak berlebihan. Selain itu, diajarkan paham bahwa dalam mengimplementasikan ajaran agama terlebih dahulu harus dipahami secara bijak dan mendalam. Moderasi beragama merupakan suatu pemahaman sikap netral, adil, dan bijak dalam menerapkan ajaran agama. Hal tersebut diilhami pada pedoman Al-Quran dan Sunnah, serta pedoman aturan bernegara dalam konstitusi, guna membentuk kesepakatan bersama yang terjadi dalam bentuk konsensus.

Kementerian Agama juga memiliki peran yang krusial dalam menanggapi pandemi COVID-19, yang tertulis dalam surat edaran Menteri Agama Nomor: SE. 1 tahun 2020 tentang Pelaksanaan Protokol Penanganan COVID-19 pada Rumah Ibadah (Agama, 2020). Edaran tersebut mengenai ajakan kepada para jajaran instansi untuk mencegah dan menanggulangi penyebaran COVID-19. Substansi edaran tersebut mengajarkan masyarakat untuk memaksimalkan kajian moderasi keberagaman dengan berbagai cara, salah satunya memaksimalkan kemampuan untuk menyampaikan materi kajian 
keagamaan secara daring dengan penggunaan konteks wacana yang dapat dimengerti kaum awam dan millenial. Majelis Ulama Indonesia (MUI) merupakan lembaga yang menaungi umat Muslim di Indonesia telah menetapkan fatwa sebagai bentuk upaya-upaya untuk menghambat penyebaran COVID-19. Fatwa-fatwa yang dikeluarkan MUI mengajarkan mengenai moderasi beragama bagi seluruh umat dengan tetap memperhatikan toleransi antar umat beragama untuk menghindari peluang konflik, sehingga fatwa MUI yang dikeluarkan dapat merangkul dan mempersuasi semua kalangan sesuai kondisi yang ada. Hal tersebut merupakan hasil analisis yang penulis lakukan dengan didukung oleh literatur penelitian yang dilakukan Syatar (Syatar dkk., 2020).

Kemudian, pertanyaan yang diajukan peneliti terhadap narasumber, "Apa peran media sosial kaitannya dengan moderasi beragama?" Terhadap pertanyaan tersebut, narasumber 11 mengungkapkan bahwa "Media sosial adalah suatu media daring yang digunakan sebagai alat tukar informasi dan berinteraksi, sehingga memudahkan aktivitas manusia. Akan tetapi, informasi dan interaksi yang tersebar dan terjadi di media sosial dapat berupa informasi dan interaksi yang baik maupun buruk. Informasi yang tersebar di media sosial belum tentu bermanfaat, seringkali informasi yang tersebar tidak terbukti kebenarannya (hoax). Peran dan kebutuhan akan media sosial di saat pandemi saat ini menjadikan media sosial sebagai sarana paling dominan yang mampu membentuk opini publik. Indonesia terdiri dari berbagai macam agama, dengan proporsi muslim lebih besar dibanding agama lain. Oleh karena keberagaman yang ada, maka perlu adanya sikap toleransi dan sikap adil antar umat beragama di Indonesia. Mengingat peran dan kebutuhan akan media sosial yang sangat tinggi, serta kaitannya dengan keberagaman beragama yang ada di Indonesia, maka sikap adil, bijak, dan toleransi dalam beragama dapat kita terapkan dan sebarkan melalui media sosial. Hal ini tentunya harus dibuat semenarik mungkin sehingga mudah dipahami dan diterima oleh masyarakat (tidak ambigu) dan dibungkus dalam bentuk yang sederhana, sehingga masyarakat akan merasa seperti sedang membaca sebuah informasi yang ringan, tetapi sebenarnya informasi yang diterima merupakan informasi mengenai moderasi beragama. Jika hal tersebut disebarkan dan dilakukan secara masif melalui media sosial, maka moderasi beragama telah diterapkan dengan baik dan dampak bermasyarakat akan positif."

Tantangan moderasi beragama merupakan realitas keberagaman di media sosial, tantangan ini terkadang menimbulkan kerisauan di kalangan ahli agama. Jika moderasi beragama tidak disikapi secara bijak, maka arus fanatisme beragama akan semakin mempengaruhi pikiran publik di media sosial. Berdasarkan imbauan Kementerian Agama sebelumnya bahwa isu moderasi beragama menjadi isu yang krusial dan diperlukan sosialisasi pikiran-pikiran yang moderat dalam beragama. Hal tersebut karena pada umumnya kalangan yang menjadi sasaran adalah masyarakat awam. Masyarakat awam lebih sering mengakses media sosial, sehingga gagasan tentang moderasi beragama harus disemarakkan.

Selain itu, pertanyaan yang diajukan peneliti terhadap narasumber, "Bagaimana menggunakan media sosial sebagai sarana moderasi agama?" Terhadap pertanyaan tersebut, narasumber 2 mengungkapkan bahwa "Karena segala aktivitas dilakukan secara daring, maka penggunaan media sosial tidak dapat dihindari. Maka melihat hal tersebut, media sosial dapat digunakan sebagai sarana beraktivitas. Kajian dan ceramah dapat dilakukan melalui media sosial. Para ulama dan pemuka agama dapat melakukan aktivitas mereka atau dengan kata lain menggunakan media sosial untuk melakukan kajian dan ceramah. Disitulah ajaran mengenai sikap toleransi, adil, dan bijak dalam bermasyarakat dan beragama dapat digaungkan. Selain itu, tenaga pendidik juga dapat menggunakan media sosial untuk menggiring peserta didik agar menanamkan sikap toleransi, adil, dan menghindari sikap ekstrim dalam menghadapi segala sesuatu. Begitu juga dengan publik figur atau bahkan masyarakat dapat membuat konten menarik, sederhana, dan ringan sehingga informasi mengenai ajakan untuk tidak esktrim dan bijak dalam menyerap informasi dan menanggapi segala sesuatu dapat diterima dengan mudah bagi kalangan tingkat apapun."

Situasi penggunaan media sosial yang demikian menjadikan keberadaan ulama, akademisi, cendekiawan, dan para praktisi sangat dibutuhkan guna menyebarkan gagasan mengenai moderasi beragama, sehingga dapat mengedukasi masyarakat.

Berkenaan dengan media, pertanyaan yang diajukan peneliti terhadap narasumber, "Media sosial apa yang sering digunakan sebagai sarana bertukar informasi dan pengetahuan mengenai moderasi beragama?" Terhadap pertanyaan tersebut, narasumber 13 mengungkapkan bahwa "Media sosial yang sering 
digunakan untuk sarana bertukar informasi adalah WhatsApp. Selain itu, media sosial Instagram juga sering digunakan sebagai sarana bertukar informasi karena seringkali mengandung gambar atau konten dengan desain yang menarik. Informasi yang tersebar di Facebook juga aktif dan masif. Melalui beberapa media sosial yang telah disebutkan, masyarakat sudah dapat memperoleh banyak sekali informasi. Sehingga sikap moderasi masyarakat dalam menyaring informasi sangat diperlukan."

Terdapat begitu banyak media sosial. Berdasarkan hasil observasi peneliti dengan mengambil sampel informasi yang berasal dari 15 narasumber, maka media sosial yang aktif digunakan sebagai sarana bertukar informasi antara lain WhatsApp, Instagram, dan Facebook. Hasil observasi langsung tersebut juga didukung oleh hasil literatur yang dilakukan peneliti mengenai penggunaan media sosial (We Are Social dan Hootsuite, 2020). Berdasarkan data penelitian tersebut, ditunjukkan bahwa penggunaan media sosial WhatsApp untuk bertukar informasi sebesar $84 \%$. Selain itu, media sosial Instagram sebesar 79\% dan Facebook sebesar 82\% dari jumlah populasi penduduk Indonesia.

\section{Kesimpulan}

Pada masa pandemi COVID-19, kebutuhan akan penggunaan teknologi tidak dapat dihindarkan, termasuk di dalamnya penggunaan media sosial. Media sosial pada masa pandemi COVID-19 sangat aktif dan masif digunakan. Media sosial digunakan sebagai sarana mendapatkan dan bertukar informasi. Akan tetapi, karena pertukaran informasi yang cepat dan masif, maka masyarakat sebagai pelaku penyebaran dan penerima informasi harus berperilaku bijak. Pemahaman mengenai sikap toleransi, adil, dan bijak sangat penting di masa pandemi, terutama di masa perubahan gaya hidup akibat pandemi seperti saat ini. Sikap moderasi beragama penting untuk diajarkan dan disebarluaskan dalam masyarakat, sehingga akan mencegah dan meminimalisir tindakan yang tidak diinginkan. Melihat ketergantungan masyarakat akan teknologi informasi termasuk media sosial, maka media sosial memiliki peran yang besar dalam membentuk sikap moderasi beragama dalam masyarakat. Media sosial harus digunakan untuk hal positif sehingga tujuan moderasi beragama dapat tercapai. Untuk mencapai hal tersebut dapat diawali dengan memahami kegunaan media sosial terlebih dahulu, kemudian mengetahui bagaimana cara menggunakan media sosial.

Media sosial dapat digunakan sebagai sarana kajian dan ceramah secara daring dan menyebarluaskan paham sikap moderasi beragama. Media sosial dapat digunakan bagi para pendidik maupun masyarakat untuk menyebarluaskan paham moderasi beragama melalui konten mendidik yang sederhana dan mudah ditangkap, sehingga terhindar dari ambiguitas. Konten dibuat semenarik mungkin sehingga akan mengundang minat masyarakat. Misal, dalam bentuk komik atau konten milenial saat ini. Peran media sosial dalam moderasi beragama sudah terlihat dari banyaknya kegiatan kajian dan ceramah yang dilaksanakan secara daring pada berbagai kota di Indonesia, salah satunya Kota Tangerang. Selain itu, konten di media sosial yang mengangkat topik mengenai moderasi beragama sudah banyak tersebar dan diciptakan. Hal tersebut umumnya tersebar aktif melalui beberapa media sosial yaitu Instagram, WhatsApp, dan Facebook.

\section{Referensi}

Agama, K. (2020). Panduan Penyelenggaraan Kegiatan Keagamaan di Rumah Ibadah dalam Mewujudkan Masyarakat Produktif dan Aman Covid -19 di Masa Pandemi. In Peraturan Menteri Agama Republik Indonesia.

Ananta, A., Nurvidya Arifin, E., Sairi Hasbullah, M., Handayani, N. B., \& Pramono, A. (2015). Demography of Indonesia's Ethnicity. In Demography of Indonesia's Ethnicity. https://doi.org/10.1355/9789814519885

Arenggoasih, R. R. W., \& Wijayanti, C. R. (2020). Pesan Kementerian Agama dalam Moderasi Melalui Media Sosial Instagram. Jurnal Jurusan Jurnalistik, 06, 160-176.

Deddy, M. (2018). Metodologi Penelitian Kualitatif: Paradigma Baru Ilmu Komunikasi dan Ilmu Sosial Lainnya. Bandung: Remaja Rosda Karya.

Lexy J, M. (2019). Metodologi Penelitian Kualitatif (Edisi Revisi). Bandung: PT. Remaja Rosda Karya.

Muhyidin, A., Rosyad, R., Rahman, M. T., \& Huriani, Y. (2020). Urgensi Penjelasan Keagamaan terhadap Keluarga Suspek Pasien Dalam Pengawasan (PDP) Covid-19 di RSU Pakuwon, Sumedang. Hanifiya: Jurnal Studi Agama-Agama, 3(1), 35-42. 
Purwanto, A., Pramono, R., Asbari, M., Budi Santoso, P., Mayesti Wijayanti, L., Chi Hyun, C., \& Setyowati Putri, R. (2020). Studi Eksploratif Dampak Pandemi COVID-19 Terhadap Proses Pembelajaran Online di Sekolah Dasar. EduPsyCouns: Journal of Education, Psychology and Counseling, 2(1), 1-12.

Rahman, M. T., \& Saebani, B. A. (2018). Membangun gerakan inklusivisme model jamaah Persatuan Islam. TEMALI: Jurnal Pembangunan Sosial, 1(1), 58-72.

Rahman, T. (2013). "Indianization” of Indonesia in an Historical Sketch. International Journal of Nusantara Islam, 1(2), 56-64.

Saenong, F. F., Zuhri, S., Hasan, H., Halimin, M., Lodji, M., Nawawi, A. M., ... Hasanuddin. (2020). Fikih Pandemi Beribadah di Masa Wabah (1st ed.). Jakarta: Nuo Publishing.

Sampurno, M. B. T., Kusumandyoko, T. C., \& Islam, M. A. (2020). Budaya Media Sosial, Edukasi Masyarakat, dan Pandemi COVID-19. SALAM: Jurnal Sosial Dan Budaya Syar-I, 7(5). https://doi.org/10.15408/sjsbs.v7i5.15210 Saraswati, D. (2013). Pluralisme Agama Menurut Karen Armstrong. Jurnal Filsafat, 23(3), 186-198. https://doi.org/10.22146/jf.32964

Syatar, A. S. A., Amiruddin, M. M., \& Rahman, A. (2020). Darurat Moderasi Beragama Di Tengah Pandemi Corona Virus Desease 2019 (Covid-19). KURIOSITAS: Media Komunikasi Sosial Dan Keagamaan, 13(1), 1-13.

We Are Social \& Hootsuite. (2019). Digital 2019. We Are Social \& Hootsuite, 76.

We Are Social \& Hootsuite. (2020). Indonesia Digital report 2020. Global Digital Insights, 247.

Wibisono, Y. M. (2016). Pluralisme Agama dan Perubahan Sosial dalam Perspektif Islam. Jurnal Agama Dan Lintas Budaya, 1, 12-24.

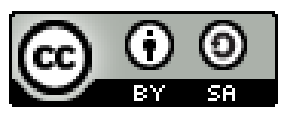

(C) 2020 by the authors. Submitted for possible open access publication under the terms and conditions of the Creative Commons Attribution (CC BY SA) license (https://creativecommons.org/licenses/by-sa/3.0/). 